\title{
Use of Ethoglucid in Treatment of Advanced Malignant Disease
}

\author{
M. R. BOND,* M.B., CH.B. ; S. D. CLARKE,* M.CH., F.R.C.S.
}

F. E. NEAL, $†$ M.B., CH.B., F.F.R., D.M.R.T.

Brit. med. F., 1964, 1, 951-953

Cytotoxic compounds used in the treatment of advanced malignant disease rarely effect cures but often relieve symptoms and prolong life. A major disadvantage has proved to be extensive haemopoietic depression resulting from bone-marrow damage due, in part, to persistence of the agent in the circulation. Localization of the compounds to the tumour-bearing area in an attempt to reduce this hazard and to achieve a higher local concentration was first described by Klopp and his co-workers (Klopp et al., 1950a, $1950 \mathrm{~b}$; Barberio et al., 1951).

This study reports a clinical trial of a new alkylating agent ethoglucid (triethyleneglycol diglycidyl ether; "epodyl,") which has been shown in animal experiments to be rapidly destroyed in the liver (Duncan, 1962), and thus possibly less damaging to the bone-marrow (Greenshields et al., 1962). In this trial attempts were made, firstly, to assess the value of ethoglucid administered intravenously in the treatment of disseminated malignant disease, and, secondly, to increase the tumour concentration by infusing it after selective arterial catheterization in patients with locally advanced malignant disease.

\section{Clinical Material}

A total of 70 patients were treated with ethoglucid between March 1961 and March 1963. Of these, 22 were treated by intravenous injection and 48 by intra-arterial infusion. The

TABLE I.-Patients Treated with Intra-arterial Ethoglucid

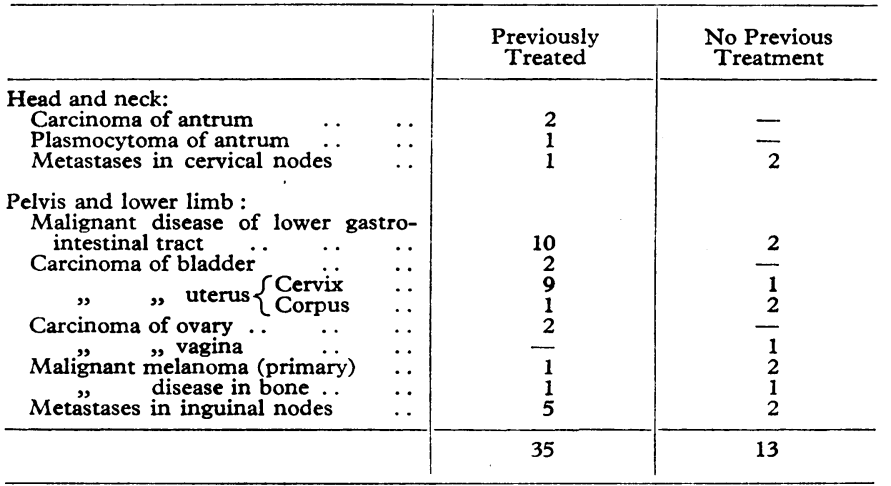

selection of cases was limited to patients under 70 years of age with advanced malignant disease. The majority had already had radiotherapy, surgery, or a combination of the two (Tables I and II); the patients accepted for treatment by intra-arterial infusion showed no evidence of disseminated metastases. Later in the trial ethoglucid was used as a primary treatment but never in preference to an acceptable alternative.

\section{Methods}

Systemic Treatment.-Patients treated by intravenous injection received a course of treatment which consisted of one to four doses, each of $250 \mathrm{mg}$. and latterly of $200 \mathrm{mg} . / \mathrm{kg}$. body weight diluted in $10 \mathrm{ml}$. of normal saline (Table II). The timing of the doses, given at three-weekly intervals, was governed by the degree of haematological depression. Routine haemoglobin estimations, differential leucocyte counts, and platelet counts showed that the maximal depression could be expected to occur between the 10th and the 17th day after injection, after which a rapid recovery to normal values took place (Fig. 1). This form of treatment was advantageous in that the patients were detained in hospital for a maximum period of 12 hours after each injection.

TABLE II.-Effect of Systemic Ethoglucid on Malignant Disease

\begin{tabular}{|c|c|c|c|c|c|c|c|}
\hline \multirow{2}{*}{$\begin{array}{l}\text { Case } \\
\text { No. }\end{array}$} & \multirow{2}{*}{ Disease } & \multirow{2}{*}{$\begin{array}{l}\text { No. of } \\
\text { Doses }\end{array}$} & \multirow{2}{*}{ mg./kg. } & \multirow{2}{*}{$\begin{array}{c}\text { Total } \\
\text { Dose } \\
(\mathrm{g} .)\end{array}$} & \multicolumn{2}{|c|}{$\begin{array}{c}\text { Response } \\
\text { (Months and Degree) }\end{array}$} & \multirow{2}{*}{ Complications } \\
\hline & & & & & Objective & Subjective & \\
\hline 1 . & $\begin{array}{c}\text { Carcinoma } \\
\text { stomach }\end{array}$ & 3 & 250 & 32.5 & - & - & Anaemia \\
\hline 2 & $\begin{array}{c}\text { Carcinoma } \\
\text { breast }\end{array}$ & 2 & 250 & $25 \cdot 0$ & $1++$ & $3++$ & Purpura \\
\hline 3 & $\begin{array}{c}\text { Carcinoma } \\
\text { stomach }\end{array}$ & 3 & 250 & $34 \cdot 5$ & $3++$ & $4+++$ & Apraemia \\
\hline $4^{*}$ & $\begin{array}{l}\text { Carcinoma } \\
\text { ovary }\end{array}$ & 3 & 250 & $45 \cdot 0$ & - & $4+++$ & 一 \\
\hline 5 & $\begin{array}{c}\text { Carcinoma } \\
\text { rectum }\end{array}$ & 3 & 250 & 31.5 & $2++$ & $6+t+$ & $\begin{array}{l}\text { Haemorrhage. } \\
\text { Anaemia }\end{array}$ \\
\hline $6^{*}$ & $\begin{array}{c}\text { Carcinoma } \\
\text { breast }\end{array}$ & 2 & 250 & 22.5 & - & $6+++$ & Anaemia \\
\hline $7^{*}$ & $\begin{array}{c}\text { Malignant } \\
\text { melanoma }\end{array}$ & 3 & 250 & 46.5 & $2+++$ & $3++$ & ” \\
\hline $8^{*}$ & ", & 4 & $\begin{array}{l}250 \\
250\end{array}$ & $\begin{array}{l}77.5 \\
44.5\end{array}$ & $2 \pm+$ & $\begin{array}{l}3++ \\
3++\end{array}$ & $"$ \\
\hline 10 & $\begin{array}{c}\text { Carcinoma } \\
\text { stomach }\end{array}$ & 1 & 250 & 15.0 & - & - & " \\
\hline $11^{*}$ & $\underset{\text { Malignant }}{\text { melanoma }}$ & 2 & 250 & $20 \cdot 0$ & $1+$ & $1++$ & " \\
\hline 12 & $\begin{array}{c}\text { Carcinoma } \\
\text { stomach }\end{array}$ & 1 & 250 & $15 \cdot 0$ & - & - & , \\
\hline $13^{*}$ & $\begin{array}{l}\text { Carcinoma } \\
\text { ovary }\end{array}$ & 3 & 250 & $24 \cdot 0$ & $2++$ & $2++$ & " \\
\hline $14^{*}$ & $\begin{array}{c}\text { Carcinoma } \\
\text { breast }\end{array}$ & 1 & 250 & $15 \cdot 0$ & - & - & $\begin{array}{l}\text { Pancytopenia. } \\
\text { Haemorrhige. } \\
\text { Terminal } \\
\text { pneumonia }\end{array}$ \\
\hline $15^{*}$ & $\begin{array}{l}\text { Carcinoma } \\
\text { ovary }\end{array}$ & 2 & 250 & $18 \cdot 0$ & - & - & Anaemia \\
\hline 16 & $\begin{array}{l}\text { Carcinoma } \\
\text { colon }\end{array}$ & 1 & 200 & $11 \cdot 5$ & - & - & $\begin{array}{l}\text { Momentary } \\
\text { cardiac arrest }\end{array}$ \\
\hline $17^{*}$ & $\begin{array}{l}\text { Carcinoma } \\
\text { ovary }\end{array}$ & 1 & 200 & $10 \cdot 0$ & - & - & Anaemia \\
\hline 18 & $\begin{array}{l}\text { Carcinoma } \\
\text { colon }\end{array}$ & 2 & 200 & $16 \cdot 0$ & - & $2+$ & - \\
\hline 19 & $\begin{array}{c}\text { Carcinoma } \\
\text { bladder }\end{array}$ & 1 & 200 & 11.5 & - & $2+$ & - \\
\hline 20 & $\begin{array}{l}\text { Carcinoma } \\
\text { tongue }\end{array}$ & 1 & 200 & $10 \cdot 0$ & - & - & 一. \\
\hline $21^{*}$ & $\begin{array}{c}\text { Malignant } \\
\text { melanoma }\end{array}$ & 2 & 200 & $30 \cdot 0$ & - & - & Anaemia \\
\hline $22 *$ & $\begin{array}{l}\text { Carcinoma } \\
\text { stomach }\end{array}$ & 1 & 200 & $9 \cdot 0$ & - & - & - \\
\hline
\end{tabular}

Anaemia $=3$ g. fall in haemoglobin during treatment. $+=$ Slight. ++ Marked. $+++=$ Complete. * Previous treatment.

Local Infusion.- The technique employed in the treatment of patients by this method involved the introduction of $a$ "kifa," or small-bore polythene catheter, into an artery supplying the tumour area. In the majority the catheters were introduced percutaneously, using the Seldinger (1953) technique under $x$-ray control, but in a few instances the catheterization was performed at open operation. In both instances the territory supplied by the catheterized artery was

* University Department of Surgery, Royal Infirmary, Sheffield. †Sheffield National Centre for Radiotherapy. 
finally checked by arteriography and by the infusion of disulphine blue. Ethoglucid was given in a total dose of $\mathbf{4 0 0}$ mg./kg. body weight, in divided doses on alternate days. The initial dose for pelvic infusions was $10 \mathrm{~g}$. followed by $5 \mathrm{~g}$. on each occasion until either the calculated dose was reached or the haemopoietic depression was such that further infusion would have proved dangerous (Fig. 2). During the twominute period of infusion, and for 10 minutes thereafter, tourniquets were applied to the upper thighs in an attempt

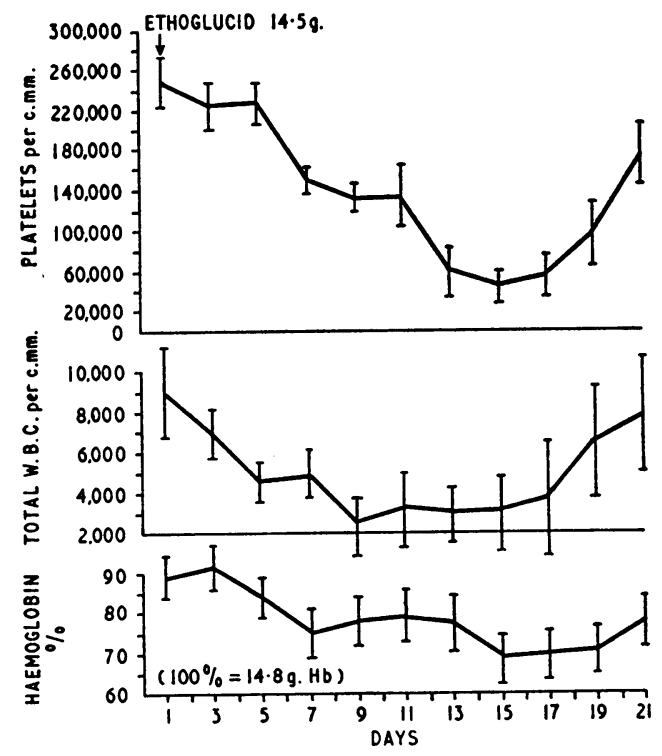

FIG. 1.-Haematological response to intravenous ethoglucid. Mean values of 10 patients each given 14.5 by intravenous injection. (Standard error of the mean is indicated for each point.)

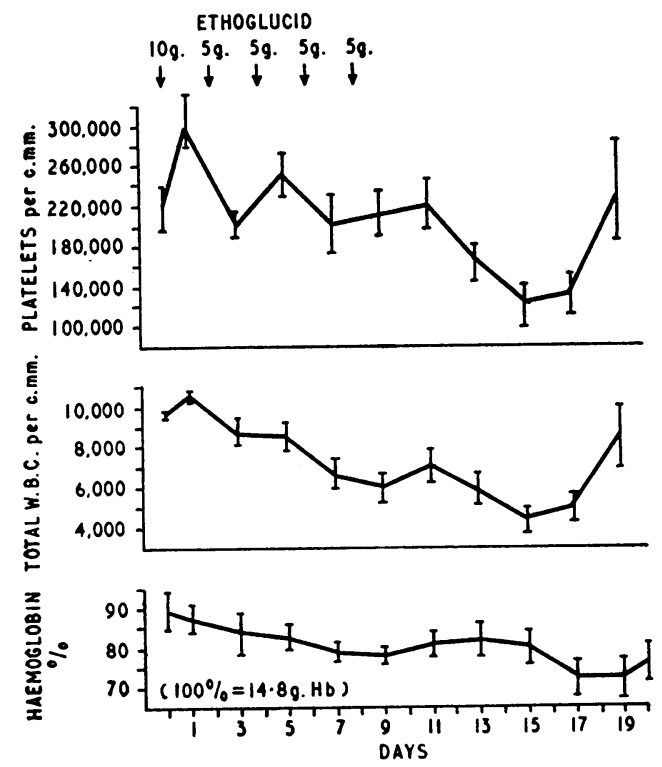

Fig. 2.- Haematological response to intermittent intra-arterial ethoglucid. Mean values of 18 patients each given a total of $30 \mathrm{~g}$. ethoglucid by intraarterial injection.

to provide a greater concentration of the drug in the pelvis. The dose of ethoglucid in head and neck infusion was limited to $10 \mathrm{~g}$. given as $2.5 \mathrm{~g}$. doses on alternate days, being diluted in $10 \mathrm{ml}$. of normal saline in all cases. In both types of infusion the patency of the catheters was maintained by flushing them with a solution of 1,000 units of heparin in $10 \mathrm{ml}$. of normal saline after each dose.
Results

The objective assessment of the response to treatment was made by serial measurements of palpable masses and by biopsy wherever possible. Measurements were made more easily in the group treated by arterial infusion, since local rather than disseminated disease was present.

Of the 22 patients treated by intravenous therapy, seven showed tumour regression, which was not, however, sustained (Table II). Histological evidence of cellular destruction in tumour tissue was noted in four of these cases.

Of the 48 patients treated by intra-arterial infusion, 10 died before treatment had been completed. Their deaths were due to advancing disease, to complications of the treatment, or to a combination of both (Table III). Tumour regression was observed in 14 of the remaining 38 patients and the impression gained at follow-up has been that fresh tumour growth is usually detectable from one to seven months after treatment.

TABLE III.-Results of Treatment with Intra-arterial Ethoglucid

\begin{tabular}{|c|c|c|c|}
\hline & & $\begin{array}{c}\text { Head } \\
\text { and Neck }\end{array}$ & $\begin{array}{l}\text { Pelvis } \\
\text { and Lower Limb }\end{array}$ \\
\hline 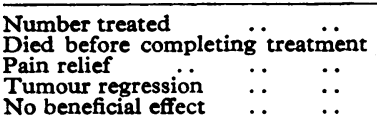 & $\begin{array}{l}\ldots \\
\cdots \\
\cdots \\
\cdots\end{array}$ & $\begin{array}{r}6 \\
2 \\
4 \\
2 \\
-\end{array}$ & $\begin{array}{r}42 \\
8 \\
27 \\
13 \\
8\end{array}$ \\
\hline
\end{tabular}

Assessment of subjective improvement was based on relief of pain, a feeling of well-being, and the ability to resume a relatively normal life. According to these criteria 12 of the 22 patients treated by intravenous injection and 31 of the 48 patients treated by intra-arterial infusion experienced benefit. The most dramatic effect was the complete relief of pain that occurred within 48 hours of the initial dose (Table III).

\section{Toxicity}

Both systemic and intra-arterial infusions were associated with variable degrees of hypotension, and nausea with vomiting in $50 \%$ of cases. The hypotension was more pronounced in the patients given systemic therapy, transitory loss of consciousness developing in several patients. Nausea and vomiting persisted for 24 hours unless controlled by an antiemetic drug. All patients showed marked epilation over the area infused.

Damage to the haemopoietic tissues is an accepted hazard in all forms of cancer chemotherapy. Despite the drug's short life in the circulation (Fig. 3), experience with ethoglucid does not differ from that with other alkylating agents in this respect. It is possible that this is because haemo-

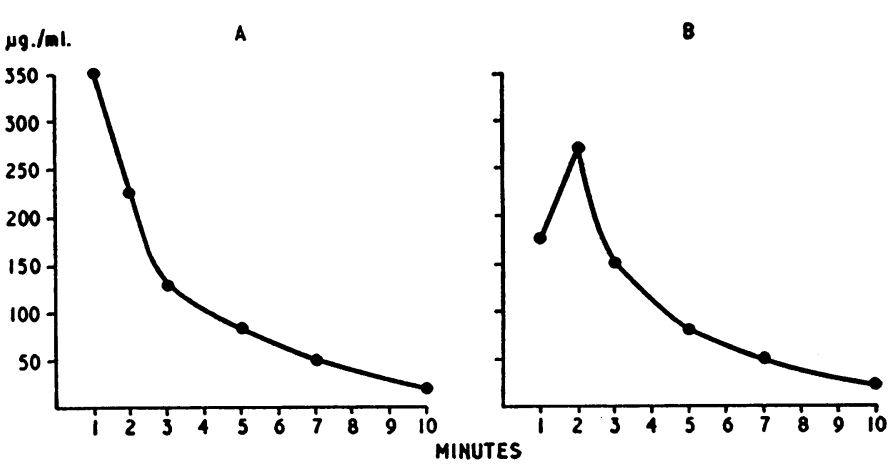

Fig. 3.-Serial blood levels of ethoglucid after intravenous and intraFIG. 3.- Serial blood levels of ethoglucid after intravenous and intraarterial injection. A, Mean values of ethoglucid levels in blood after an
intravenous injection of $10 \mathrm{~g}$. in each of 13 patients. B, Mean values of intravenous injection of $10 \mathrm{~g}$. in each of 13 patients. B, Mean values of ethoglucid levels in blood after an intra-arterial 
poietic depression is taken as one of the criteria of adequate dosage. The depression produced in patients treated by intravenous injection occurred more rapidly and to a greater degree than in patients who received intermittent intraarterial infusion, in whom some measure of bone-marrow protection was achieved by fractionation of the total dose (cf. Figs. 1 and 2). Of the patients with marked haemopoietic depression, only a minority required blood transfusion for anaemia ; but one patient in whom thrombocytopenia was followed by severe rectal haemorrhage required transfusion with platelet-rich blood. Antibiotic cover was given when the leucocyte count fell below 1,000 cells per c.mm. or when an infection became apparent.

\section{Complications}

The use of an intra-arterial technique in addition to the systemic effects of the cytotoxic agent leads to problems related to the presence of the catheter. Six patients developed septicaemia and four of them died. Arterial thrombosis was encountered once in the series of pelvic infusions, but this did not lead to ischaemic changes in the limb. However, thrombosis of the external carotid artery leading to extensive local tissue necrosis occurred during an infusion of the head and neck region. Wound infection at the site of the percutaneous puncture occurred to a varying degree in many patients, and in one case this led to persistent arterial bleeding necessitating ligation of the external iliac and common femoral arteries. The incidence of neurotoxicity was not high: of six patients developing functional loss of limb musculature complete recovery occurred in five, residual footdrop remaining in the sixth (Table IV). A combination of toxic effects and "catheter" complications were seen in a small number of patients.

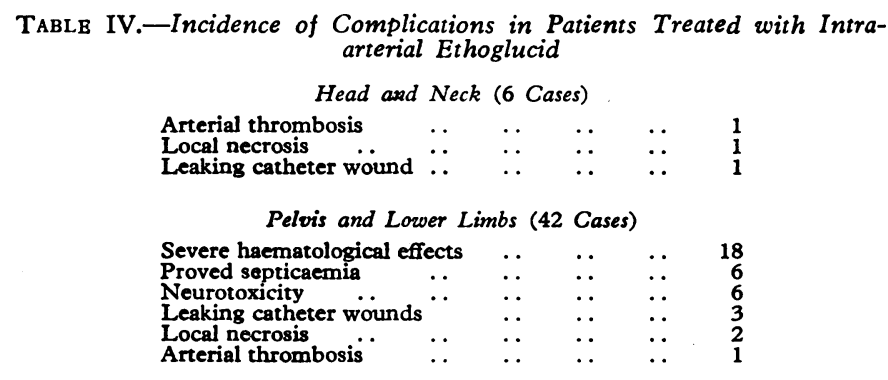

\section{Conclusion}

This clinical trial may be regarded primarily as an attempt to achieve palliation in patients with advanced malignant disease : 47 had already had surgical or radiotherapeutic treatment, but the remaining 23 were treated with ethoglucid as a first choice, either because the disease was far advanced or as a preliminary procedure.

Irrespective of the method of administering ethoglucid, symptomatic relief outweighed objective improvement in all patients. The swift relief of pain, which was a striking feature in both groups, was associated with a feeling of wellbeing, permitting many patients to continue a relatively normal life for a period of weeks to months. The mechanism of pain relief is not fully understood, but available evidence points to local nerve-destruction (Westbury, 1962 ; Mahaley and Woodhall, 1962). This sensory neurotoxic effect of ethoglucid is of great value in treatment, and our observations suggest that only rarely are main nerve trunks permanently damaged.

Objective relief was observed less often, but the difficulty in obtaining tissue for histology and in making serial measurements of intrapelvic or disseminated tumour masses may be in part responsible. Both surgery and radiotherapy lead to impairment of tumour blood-supply, and it is possible that this reduces the quantity of drug reaching the tumour to ineffective levels.

The number and severity of complications together with the modest therapeutic return may act as a deterrent to those contemplating the use of cytotoxic agents by these methods. However, experience of work in progress at the present time indicates that most of the complications due to an indwelling arterial catheter can be reduced by giving the course of treatment over a much shorter period. Recent evidence demonstrates that a dose of $10 \mathrm{~g}$. of ethoglucid given by intracarotid injection during general anaesthesia leads to satisfactory tumour regression and symptomatic relief (Harrison, 1963).

In view of the variable and often short response to treatment, a trial has been planned in which patients selected at random from a group will be given maintenance therapy with an oral alkylating agent after infusion with ethoglucid. Their progress will be compared with the remainder of the group, who will receive infusion with ethoglucid alone. By this means it is hoped to evaluate the effectiveness of the combination of infusion with oral maintenance therapy.

\section{Summary}

The result of a clinical trial using a new alkylating agent, ethoglucid (" epodyl "), in the treatment of advanced malignant disease is presented.

Treatment was carried out in 22 patients by intravenous injection and in 48 by intra-arterial infusion. Of the former group, 7 showed objective and 12 subjective improvement ; is the latter group 14 showed objective and 31 subjective improvement.

Varying degrees of local and systemic toxicity were encountered. Of the 70 patients treated 22 experienced serious toxic effects, and in 12 there were complications associated with the presence of an intra-arterial catheter.

Treatment with ethoglucid alone is not advised unless conventional forms of therapy have been considered as unsuitable or, alternatively, have been considered as a suitable second stage in the management of any particular patient.

The ethoglucid used in this study was supplied by Impertal Chemical Industries through the courtesy of Dr. W. H. W. Inman, to whom we are grateful for his invaluable assistance. We wheh to thank Dr. N. Lewtas and the junior members of the staff of the radiology department of the Royal Infirmary, Sheffield, who were responsible for most of the intra-arterial catheterizations. We thank the consultants of the Sheffield National Centre for Radiotherapy, the Royal Infirmary, Sheffield, and Professor A. W. Kay for referring cases and for their helpful criticisms of this work. The financial support of the British Empire Cancer Campaign has enabled background experimental work to be done in this clinical trial, and for this support we are grateful.

\section{REFRRENCES}

Barberio, J. R., Klopp, C. T., Ayres, W. W., and Gross, H. A. (1951). Cancer (Philad.), 4, 134i.

Duncan, W. A. M. (1962). Personal communication.

Greenshields, J. M., Langley, B. W., Vickers, E. J., Walpole, A. Ln, and Williams, M. H. C. (1962). Personal communication.

Harrison, D. F. N. (1963). Y. Laryng., 77, 509.

Klopp, C. T., Alford, T. C., Bateman, J., Berry, G. N., and Winshlp, T. (1950a). Ann. Surg., 132, 811.

Bateman, J., Berry, N., Alford, C., and Winship, T. (1950b). Cancer Res., 10, 229.

Mahaley, M. S., and Woodhall, B. (1962). Cancer Chemother. Rep., 16, 543.

Seldinger, S. I. (1963). Acta radiol. (Stockh.), 39, 368.

Westbury, G. (1962). Proc. roy. Soc. Med., 55, 643. 